\title{
Charakterystyka wietnamskiego przedsiębiorcy w Polsce - analiza metafor
}

\begin{abstract}
Agnieszka Brzozowska*
Artykut opisuje wyniki badania jakościowego polegajacego na przeprowadzeniu wywiadów pogtębionych na 20 wietnamskich przedsiębiorcach funkcjonujacych w Polsce. Celem badania byto scharakteryzowanie środowiska przedsiębiorców wietnamskich w Polsce. Aby zrealizować cel i pogtębić dyskusję, podczas rozmowy postużono się metafora zwierzęcia. Badani proszeni byli o porównanie przedsiębiorców wietnamskich do zwierzęcia i uzasadnienie przypisanym im cech. Część badanych zauważyta, że pokolenie pierwsze i drugie imigrantów różni się od siebie pod względem pracowitości, czasu wolnego i podejścia do pieniędzy. Dla części Wietnamczyków spoteczność byta homogeniczna niezależnie od tego, czy to byto pierwsze czy drugie pokolenie. Mimo przedstawiania różnych zwierząt, opisywane przez nich cechy sa spójne. Badanie pokazuje w jaki sposób przedsiębiorcy wietnamscy postrzegaja swoja spoteczność.

Słowa kluczowe: metafory, przedsiębiorczość imigrantów, Wietnamczycy w Polsce, techniki projekcyjne.

Nadesłany: 13.07.18 | Zaakceptowany do druku: 21.11.18

\section{Characteristics of Vietnamese entrepreneur in Poland - metaphor analysis}

The following paper describes the results of a qualitative study involving in-depth interviews on 20 Vietnamese entrepreneurs operating in Poland. The aim of the study was to characterize the society of Vietnamese entrepreneurs in Poland. To achieve the goal, the Author used during the conversation a metaphor of the animal to deepen the discussion. The respondents were asked to compare the Vietnamese entrepreneurs to the animal and justify the features assigned to them. Some respondents noticed that the first and second generation of immigrants are different in terms of diligence, leisure time and approach to money. For some of the Vietnamese, the community was homogenous regardless of whether it was the first or the second generation. Despite presenting different animals, the features they describe are consistent. The study shows how Vietnamese entrepreneurs perceive their community.
\end{abstract}

Keywords: metaphors, immigrant entrepreneurship, Vietnamese in Poland, projection techniques.

Submitted: 13.07.18 | Accepted: 21.11.18

JEL: L26, J15

\footnotetext{
* Agnieszka Brzozowska - dr, Wydział Zarządzania, Uniwersytet Warszawski. https://orcid.org/00000002-9908-6427.

Adres do korespondencji: Wydział Zarządzania, Uniwersytet Warszawski, ul. Szturmowa 1/3, 02-678 Warszawa; e-mail: abrzozowska@wz.uw.edu.pl.
} 


\section{Wstęp}

Według analiz Castles i Miller (2011) do lat 70. prowadzenie własnych firm nie było zbyt popularne wśród imigrantów, którzy zarabiali na utrzymanie, raczej pracując najemnie. Sytuacja zmieniła się w latach 80., gdy wyraźnie można było zauważyć wzrost liczby osób prowadzących działalność gospodarczą wśród migrantów. Od tego momentu szczególnie intensywnie zaczęto prowadzić badania nad przedsiębiorczościa imigrantów.

Przedsięwzięcia biznesowe prowadzone przez migrantów często konkuruja z firmami prowadzonymi przez lokalnych mieszkańców długimi godzinami pracy, które wymagane są również od zatrudnionych w tychże firmach. To z kolei prowadzi do trudności w znalezieniu pracowników oraz zatrudniania przede wszystkim osób pochodzących z tej samej grupy etnicznej, tylko te osoby są bowiem w stanie przystać na tak niedogodne warunki pracy ze względu na brak alternatywy miejsca pracy oferujacego rynkowe warunki zatrudnienia. Pracownicy ci często, z tych samych względów, godzą się również na gorsze warunki zatrudnienia i są bardziej elastyczni (Min i Bozorgmehr, 2003). Archetyp przedsiębiorstwa prowadzonego przez imigrantów to niewielki sklep lub bar prowadzony przez małżeństwo. Obecnie wizerunek przedsiębiorcy imigranta jest już nieco inny i możemy obserwować coraz większy udział przedsiębiorców imigrantów mających swój udział w bardziej zaawansowanych formach biznesu (Kloosterman i Rath, 2010). Nadal jednak, duża część firm jest prowadzona wspólnie przez członków rodziny, a i pracownicy nierzadko do niej należą. Firmy te zaś nie rozwijają się za bardzo i często pozostają na etapie małych działalności gospodarczych w typowych dla imigrantów branżach (Light i Bonacich, 1988). Z obserwacji wynika, że migranci najczęściej zakładają firmy, takie jak: etniczne restauracje, sklepy spożywcze czy osiedlowe sklepy wielobranżowe (Waldinger, Aldrich i Ward, 1990). Czesść imigrantów swoją działalność prowadzi tylko w obrębie rynku należącego do niszy etnicznej (Auster i Aldrich, 1984). Jest to jedna z częściej i bardziej oczywistych dróg wybieranych przez imigrantów (Castles i Miller, 2011).

W Polsce, do tej pory, przedsiębiorczość imigrantów rzadko była przedmiotem badań. Wynikało to $\mathrm{z}$ faktu, że po pierwsze samo zjawisko przedsiębiorczości jest zjawiskiem relatywnie nowym, ponieważ dopiero od 1989 roku można mówić o wolnym rynku. Poza tym Polska dopiero staje się krajem, który zaczyna być miejscem docelowym migracji. W związku $\mathrm{z}$ tym od kilku lat można zaobserwować wzrost zainteresowania badaczy tą tematyką (Andrejuk, 2016; Brzozowski, Glinka i Brzozowska, 2015; Glinka, 2018), co jest też związane $\mathrm{z}$ rozwojem ogólnie przedsiębiorczości w Polsce (Dubel, 2006; 2017).

Wietnamczycy sa obecni w Polsce od ponad dwudziestu lat. Pierwsza fala migrantów wietnamskich składała się z osób dobrze wykształconych, specjalistów, którzy zapoczątkowali aktywność ekonomiczna Wietnamczyków w naszym kraju. Oni również nadali kierunek i charakter przedsiębiorczości wietnamskiej w Polsce, koncentrując się głównie na handlu i gastronomii. Odpowiedzialni też byli za napływ kolejnych grup imigrantów (Wysieńska i Piłat, 2012). Aktualnie stanowią oni najliczniejszą społeczność migrantów pochodzących spoza europejskiego kręgu kulturowego (GUS, 2015). Są grupą cudzoziemców, która charakteryzuje się najwyższym odsetkiem przedsiębiorców w porównaniu $\mathrm{z}$ innymi grupami obcokrajowców zamieszkujących Polskę (Kępińska, 2005). W 2005 roku aż 76\% Wietnamczyków prowadziło własne firmy (Górny, 2005).

W Polsce Wietnamczycy prowadzą swoje firmy przede wszystkim w branżach handlu, gastronomii i usługach, przy czym świadczenie usług nastawione jest głównie na zaspokajanie potrzeb klienta wietnamskiego. Natomiast firmy zajmujące się handlem i gastronomia powstają z myślą głównie o kliencie polskim. Prowadzą oni zwykle mikro- i małe firmy, nie przekraczając raczej liczby pięciu zatrudnionych. Tylko nieliczni prowadzą średnie i duże przedsiębiorstwa (Górny, 2005).

\section{Metafora techniką projekcyjną}

Techniki projekcyjne wywodzą się psychiatrii, dopiero z czasem zaczęły służyć innym celom, a szczególnie upodobali sobie je badacze zajmujący się badaniami marketingowymi (Maison, 2004, s. 166-200), ale również badacze z dziedziny zarządzania, 
badający m.in. relacje pracodawca - pracownik (Pawłowska i Postuła, 2014).

„Projekcja w pierwotnym znaczeniu psychoanalitycznym to sytuacja, gdy osoba wyrzuca z siebie i przypisuje otoczeniu swoje nieakceptowane cechy, uczucia, pragnienia. Techniki projekcyjne w klasycznej swojej formie służa zatem diagnozowaniu odrzucanych lub nieuświadamianych przez człowieka obszarów jego osobowości” (Maison, 2010, s. 166).

Metafora pozwala pokazać coś, co jest widoczne, ale mimo to - niewidziane. Dopiero opowiedzenie o danym zjawisku nie wprost pozwala uchwycić jego sedno i nature (Morgan, 2006). Ludzie zapytani wprost czasami odpowiadają niezgodnie z rzeczywistymi motywami. Nie wszystkie procesy emocjonalne są uświadomione, a do niektórych z powodu checci zachowania pewnego wizerunku badani nie chca się przyznać. W takich sytuacjach dobrym narzędziem wydają się być techniki projekcyjne (Branthwaite i Lunn, 1985), które nazywane są w marketingu pośrednim zadawaniem pytań (Bellenger, Bernhardt i Goldstucker, 1976).

„Materiał projekcyjny w większym stopniu niż materiał jednoznacznie ustrukturalizowany umożliwia diagnoście zaobserwowanie indywidualnych rysów osobowości osoby badanej, daje lepszy wgląd w fenomenologiczny świat jej przeżyć, pozwala rozpoznać jej osobiste wzorce strukturalizowania i komunikowania doświadczenia, ujawnia dominujący domyślny kontekst społeczny jej działań" (Stemplewska-Żakowicz, 1998, s. 14).

Ogólnie badania projekcyjne stosowane są, gdy:

- badani mogą mieć opory przed bezpośrednim ujawnieniem swoich poglądów czy to z powodu obawy o akceptację społeczną, czy też z powodu intymności, czy drażliwości tematyki;

- badani mogą nie zdawać sobie sprawy z rzeczywistych motywów swojego zachowania;

- problemy badawcze moga być trudne do zwerbalizowania i łatwiej jest opowiedzieć o czymś w sposób symboliczny czy pośredni, do czego szczególnie polecana jest animizacja, czyli wyobrażanie sobie np. produktu jako zwierzęcia lub personifikacja, czyli wyobrażenie sobie np. marki jako osoby;

- chcemy poznać niezależne opinie uczestników grupowej dyskusji, sprawdzając spójność wypowiedzi w grupie z zadaniami wykonanymi indywidualnie;

- prowadzimy przedłużone zogniskowane wywiady grupowe i potrzebujemy urozmaicić badanie, aby zaktywizować badanych (Maison, 2010, s. 170).

Ponadto „Ludzie za pomoca metafor doświadczają świata, angażują się weń i rozumieja go" (Kostera, 1996, s. 40).

Biorąc pod uwagę wszystkie kryteria uznano, że tematyka badania pasuje do większości obszarów rekomendowanych do badania techniką projekcyjną. W badaniu zdecydowano się zastosować zadanie wykonywane indywidualnie i polegające na animalizacji, czyli wyobrażeniu sobie przedsiębiorcy jako zwierzęcia (Levy, 1985). Pod koniec rozmowy proszono badanych, aby wyobrazili sobie wietnamskiego przedsiębiorce jako zwierze i następnie uzasadnili swój wybór. Prośba o uzasadnienie była istotnym elementem tej techniki, gdyż przede wszystkim na uzasadnieniu bazuje później cała analiza. Czasami skojarzenia badanych mogą mocno odbiegać od stereotypowych skojarzeń. Dodatkowo, badając osoby wychowane w innej kulturze, należało wziąć pod uwagę, że niektóre zwierzęta kojarzone z pewnymi cechami mogą być bliskie tylko Polakom, a zupełnie inaczej interpretowane są wśród innych nacji. Ujawniło się to zwłaszcza przy metaforze psa, gdzie pies nie był dobrze kojarzony przez wietnamskiego przedsiębiorcę, w przeciwieństwie do pozytywnego wizerunku tego zwierzęcia wśród Polaków. Był to sygnał, że przez cały czas należy być czujnym i otwartym na informacje pochodzące $\mathrm{z}$ terenu.

\subsection{Metafora zwierzęcia}

Zdecydowano się na wybór metafory zwierzęcia z kilku powodów. Po pierwsze zwierzęta są częstymi wyrażeniami totemizmu w społeczeństwach prymitywnych (Spears i in., 1996) i totemiczne duchy są duchami o znaczeniu społecznym (Burton, 1974; Evans-Pritchard, 1956), a znaczenie zwierzęcia jest kulturowo przypisane przez ludzi (Spears i in., 1996). Z tego punktu widzenia wyobrażenie sobie przedsiębiorcy jako zwierzęcia i nadanie mu pewnych ludzkich cech nie powinno stanowić problemu, gdyż jest to działanie wykonywane od wieków niezależnie od pochodzenia. Kulturowe znaczenie zwierząt sugeruje, że ludzie identyfikują się z postaciami zwie- 
rząt, ponieważ nadają im standardowe ludzkie cechy (Neal, 1985; Sax, 1988). Ludzie mają naturalną tendencję do personifikowania różnych obiektów i myślenia o nich za pomocą cech ludzkich (Taylor, 1898). Warto również podkreślić, że te same obrazy i symbole są ważne w wielu różnych kulturach (Jung, 1981). Metafora zwierzęcia pozwala zachować emocjonalny dystans podczas rozmowy na drażliwe tematy, pozwala zachować twarz, gdy pojawiają się trudne tematy (Dyson i Genishi, 1994), a takim tematem jest właśnie rozmowa o społeczności pochodzenia dla imigranta.

\section{Metoda badania i uzasadnienie jej wyboru}

Celem prowadzonego badania była eksploracja terenu i chęć poznania świata przedsiębiorców wietnamskich. Cel taki przyjmuje się, kiedy zakres poszukiwań badawczych dotyczy nowej problematyk (Babbie, 2008). Ponadto, wybrany temat, charakteryzuje się dużą dynamiką zmian, którą trudno byłoby uchwycić w ankietach. Kultura przedsiębiorców wietnamskich jest stale definiowana, gdyż w Polsce mamy do czynienia zaledwie $\mathrm{z}$ dwoma pokoleniami imigrantów wietnamskich, a jak pisze Konecki (2010, s. 13) „wywiady pozwalają wychwycić wielość światów życia". W celu wychwycenia procesów formowania się społeczności wietnamskich przedsiębiorców w Polsce, ważne było przeprowadzenie konwersacji z osobami należącymi do tego świata. Warto również wspomnieć o tym, jak rozumiano kulturę. Pojęcie „kultury” określane jest jako zbiór wartości i norm oraz wzorów zachowań, które obowiązują w danym społeczeństwie (Konecki, 2010). Według Prusa kultura podlega nieustającemu procesowi zmian. Jest czymś więcej niż język, ale jest z językiem związana choćby dlatego, że opiera sie na zasobach wiedzy ludzkiej, która przekazywana jest za pomoca języka. Podstawą przedsięwzięcia badawczego było zrozumienie motywów, działań, relacji oraz znalezienie definicji siebie, jaką konstruują członkowie społeczności wietnamskich przedsiębiorców.

W latach 2012-2015 przeprowadzono wywiady pogłębione z 20 przedsiębiorcami wietnamskimi funkcjonującymi na terenie całej Polski. Wywiady trwały średnio ok. 60 minut. Zostały nagrane, spisane, a następnie stworzono kody i przeprowadzono analize materiału badawczego. Dobór badanych odbywał się za pomocą metody kuli śniegowej oraz doboru celowego, ponieważ chciano pozyskać jak największa różnorodność pod wzgleddem wieku, branży i strategii działania wśród badanych.

\subsection{Ograniczenia wybranych metod}

Wybierając metodę swobodnego wywiadu częściowo ustrukturalizowanego, zdawano sobie sprawę z ograniczeń, jakie to ze sobą niesienie (Glinka i Hensel, 2018). Uzyskiwane z wywiadów dane były doświadczeniami badanych oraz ich interpretacjami faktów (Silverman, 2009), co niewątpliwie nie stanowi obiektywnych informacji o faktach dotyczacych przedsiębiorczości wietnamskich imigrantów w Polsce. Jednak charakter badań był eksploracyjny, a ich celem było zrozumienie, w jaki sposób badani odbierają rzeczywistość i co jest dla nich ważne. Założenia badawcze zostały więc spełnione.

Techniki projekcyjne będą narażone na największe obiekcje, gdyż charakteryzują się dużą dowolnością w zakresie interpretacji (Kreuger, 1994). Jednak celem nie było stawianie diagnozy, a rozwinięcie konwersacji i pogłębienie tematu charakterystyki przedsiębiorców przy wykorzystaniu tych technik. Zamiarem było również, aby poprzez tworzenie metafor badani spojrzeli z innej perspektywy na bycie wietnamskim przedsiębiorca w Polsce, czyli użycie jej jako kreatywnego sposobu uchwycenia natury tego zjawiska (Morgan, 2006, s. 34). Zdawano sobie sprawę również z możliwego wpływu kultury polskiej, w której badacz jest zakorzeniony, na sposób interpretowania danych otrzymanych szczególnie w części projekcyjnej. Pamiętano, że

„ryba odczuwa brak wody tylko wówczas, gdy już w niej nie przebywa. Kultura jest jak woda dla ryby. Podtrzymuje nas przy życiu. Żyjemy i oddychamy przez nią. To, co dla jednej kultury uważane jest za istotne, np. pewien poziom dobrobytu, dla innych kultur może być nieistotne" (Trompenaars i HampdenTurner, 1999, s. 20).

Dopytywano więc badanych o ich własne interpretacje zaproponowanych przez nich metafor. Rorty (1999, s. 257) uzasadniał użycie metafor, pisząc: 
„Pytać o to jak działa metafora, to tak, jak pytać o to, jak działa geniusz. Gdybyśmy to wiedzieli, geniusz byłby zbyteczny. Gdybyśmy wiedzieli, jak działają metafory, byłyby one niczym sztuczki magika: raczej sprawa rozrywki niż (..) niezbędnymi narzędziami postępu moralnego i intelektualnego".

\section{Analiza}

Niektórzy rozmówcy podkreślali różnicę między pierwszym i drugim pokoleniem imigrantów prowadzących firmy, przestawiając dwie różne metafory, dla pierwszego i drugiego pokolenia. Analiza wyboru metafor zwierząt, które miałyby charakteryzować wietnamskich przedsiębiorców prowadzących firmy w Polsce, rozpoczyna sie od wypowiedzi, w których badani wykorzystywali wspólną metaforę dla obu pokoleń. W tabeli 1 przedstawiono zestawienie metafor użytych przez interlokutorów. Każda z metafor ujętych w tabeli ma po jednym wskazaniu. Wyjątkiem są metafory: kota i bawoła, które pojawiły się dwukrotnie. Przedstawiono je jednak oddzielnie, ponieważ uzasadnienia użycia tych metafor bardzo się różniły.

Mrówki wymieniane były jako bardzo pożyteczne zwierzęta, tworzace społeczności, w których każdy osobnik specjalizuje się w danym typie zadań wykonywanych na rzecz całej społeczności. Praca służy wspólnemu dobru, pracuja na rzecz gniazda, w którym żyją wszystkie mrówki. Mrówki opisywane sa jako bardzo pracowite owady. I takie właśnie cechy przedsiębiorców wietnamskich podkreślali badani.

Kolejnym zwierzęciem, które pojawiło się jako metafora była pszczoła. Badana, która wybrała tę metaforę uzasadniała ją również pracowitością wietnamskich przedsiębiorców oraz solidarnością i tworzeniem grupy, w której każdy może liczyć na pomoc. Dodatkowo podkreśliła, że ważną jednostką w społeczności wietnamskiej jest rodzina, która znajduje sie w centrum, podobnie jak w ulu królowa. Według rozmówczyni Wietnamczycy tworzą dość zamkniętą grupę i są bardzo skupieni na zarabianiu pieniędzy, dzięki którym utrzymują rodziny.

Sowa występuje $\mathrm{w}$ języku polskim w związku frazeologicznym: „mądry jak sowa" i tak też opisywał przedsiębiorców wietnamskich mój rozmówca. Podkreślał, że Wietnamczycy są roztropni i podejmują mądre decyzje. Jednak nie jest to, według badanego, najlepsza metafora, ponieważ sowy nie są zdeterminowane, wytrwałe. Wietnamczycy zaś są bardzo uparci i łatwo się nie poddają.

Kota jako metaforę wybrały dwie osoby. Jeden $\mathrm{z}$ badanych uzasadniał wybór kota, opisując wietnamskich przedsiębiorców jako przebiegłych i wahających się, nie podejmujących szybko decyzji, a czających się i obserwujących wydarzenia. Według badanego, Wietnamczycy myśla zbyt lokalnie i skupiają się na bliskich celach. Druga badana osoba opisywała Wietnamczyków jako mądrych, zwinnych, którzy są w stanie znaleźć się w każdym miejscu, w którym chcą. Uważała również, że jeśli Wietnamczycy czegoś pragną, to nie ma takiej przeszkody, której by nie pokonali. Z reguły wietnamscy przedsiębiorcy „chodzą cicho na paluszkach i nie robia $\mathrm{z}$ tego wielkiego hałasu". Według rozmówczyni, wietnamska społeczność unika rozgłosu i stara się, aby jak najmniej o niej mówiono. Nie potrzebuja być widoczni, żeby być skutecznymi.

Dwukrotnie jako metafora został wybrany również bawól. Pierwszy badany opisywał społeczność przedsiębiorców wietnamskich jako ciężko pracujących i wytrwałych, bardzo łagodnych w swoim postępowaniu i usłużnych. Uważał, że wietnamscy przedsiębiorcy zyskują sympatię innych ludzi, ponieważ są mili i uprzejmi. Druga osoba, która również wybrała za metafore bawoła, kierowała się głównie pracowitością. Jednak uważała również, że nie jest to idealna metafora, ponieważ bawół jest głupim zwierzęciem i robi tylko to, co inni mu karzą, a Wietnamczycy tacy nie są.

Badany, który wybrał węża jako metaforę uzasadniał wybór tym, że wietnamscy przedsiębiorcy sa sprytni i szybcy w działaniu. Nie zastanawiają się za długo nad decyzją, gdyż liczy się to, aby jak najszybciej wykonać ruch i być pierwszym. Rozmówca uważał też, że Wietnamczycy nie są zbyt lubiani w Polsce. Wynika to przede wszystkim z tego, że Polacy nie do końca wiedzą, czego moga sie spodziewać po Wietnamczykach. Podobny strach jest odczuwany przed wężami.

Badana, która porównała wietnamskich przedsiębiorców do szczura, uzasadniała wybór tym, że Wietnamczycy, podobnie jak szczury, potrafią znaleźć wyjście z każdej sytuacji. Doskonale orientują się w otoczeniu i relacjach. Początkowo trudno im zaufać innym osobom, można nawet powie- 
Tabela 1. Metafory zwierząt jako przedsiębiorców wietnamskich

\begin{tabular}{|c|c|}
\hline Zwierzę & Uzasadnienie \\
\hline Sowa & $\begin{array}{l}\text { - uosobienie mądrości } \\
\text { - roztropności }\end{array}$ \\
\hline Pszczoła & $\begin{array}{l}\text { - } \text { zawsze pracują w grupie } \\
\text { - pomocni sobie } \\
\text { - w ulu jest królowa matka, w przypadku Wietnamczyków taką rolę będzie odgrywać } \\
\text { rodzina; to na nią pracują Wietnamczycy } \\
\text { - bronią swojej własności } \\
\text { - dość zamknięta grupa } \\
\text { - skupienie na jednym celu - zarabianiu pieniędzy }\end{array}$ \\
\hline Mrówki & $\begin{array}{l}\text { - dużo pracują } \\
\text { - biorą na siebie większy ciężar niż mogą udźwignąć }\end{array}$ \\
\hline & $\begin{array}{l}\text { - } \text { przebiegli } \\
\text { - wahający się } \\
\text { - myślący zbyt lokalnie } \\
\text { - idąc za łatwymi zarobkami, rezygnują z większych możliwości }\end{array}$ \\
\hline Kot & $\begin{array}{l}\text { - mądry } \\
\text { - chodzi na paluszkach i nie robi z tego wielkiego hałasu, ale i tak dostanie to, czego } \\
\text { chce } \\
\text { - zwinny } \\
\text { - wszędzie się wciśnie } \\
\text { - jak będzie chciał, to poprosi }\end{array}$ \\
\hline Wąż & $\begin{array}{l}\text { - } \text { sprytni } \\
\text { - } \text { szybcy } \\
\text { - jeśli inni są mili to wąż też, ale jeśli są agresywni to uciekają } \\
\text { - podobnie jak z wężem w Polsce, dużo ludzi ma problem z Wietnamczykami, bo nie } \\
\text { wiedzą, czego mogą się po nich spodziewać }\end{array}$ \\
\hline \multirow[t]{2}{*}{ Bawół } & $\begin{array}{l}\text { - ciężko pracuje } \\
\text { - wytrwały } \\
\text { - lagodny } \\
\text { - usłużny } \\
\text { - ludzie przy bawole czują się rodzinnie }\end{array}$ \\
\hline & - pracowity \\
\hline Szczur & $\begin{array}{l}\text { - } \text { wszędzie się prześlizgnie } \\
\text { - zawsze znajdzie wyjście } \\
\text { - gromadzi kapitał } \\
\text { - ma mnóstwo dzieci } \\
\text { - wszystkich zna, całą okolicę } \\
\text { - wie gdzie iść } \\
\text { - trochę bojaźliwy, ale jak się oswoi to je z ręki } \\
\text { - jak jest zadowolony, to pozwala sobie na dużo } \\
\text { - czasem potrafi być denerwujący } \\
\text { - jest potrzebny }\end{array}$ \\
\hline
\end{tabular}

Źródło: opracowanie własne.

Wydział Zarządzania UW https://doi.org/10.7172/1733-9758.2018.29.9 
dzieć, że są bojaźliwi, ale z czasem, kiedy się oswoją, poznają, będą ,jedli z ręki”. Wietnamscy przedsiębiorcy gromadzą kapitał jak zwierzęta $\mathrm{z}$ rodziny myszowatych. Uważa też, że Wietnamczycy potrafią być irytujący z powodu swojej wszędobylskości i ciekawości. Uznaje jednak, że są oni potrzebni w społeczeństwie i mają swoją rolę do odegrania.

Podsumowując, można zauważyć, że wybierane zwierzęta są spokojne, niezwracające na siebie uwagi i pracowite. Mozolnie zbierają kapitał na później, są zaradne i wytrwałe. Pojawiał się też obraz Wietnamczyków szybkich i skutecznych. W każdym jednak przypadku badani podkreślali pozytywne nastawienie przedsiębiorców, skupienie na pracy i chęć pozostania niezauważonym i niekłopotliwym.

Pozostali rozmówcy tworzyli metafory, rozróżniając pierwsze i drugie pokolenie migrantów. Zestawienie metafor dla pierw- szego pokolenia wietnamskich przedsiębiorców prowadzących swoje firmy w Polsce zaprezentowano w tabeli 2. Każda metafora przedstawiona $\mathrm{w}$ tabeli zawiera po jednym wskazaniu.

Jak można zauważyć, niektóre z metafor się powtarzają. Jedną z nich jest bawól. Jeden $\mathrm{z}$ rozmówców motywował wybór tej metafory ciężką pracą wietnamskich przedsiębiorców: „pracuje, pracuje i tak nie chce się kłócić z nikim, aby pracować, aby mieć jedzenie" [R17p]. W tej grupie metafor pojawiły się ponownie opinie, że Wietnamczycy nie lubią rozgłosu i preferują spokojną pracę: „bawół ma pracować 12 godzin, to pracuje i ten bawół cichy, cichy...” [R17p]. Nieważne jest zmęczenie, ważne są cel i praca. Często pracują ponad siły, żeby zapewnić byt rodzinie.

Mrówki są kolejną ponownie wspominaną metaforą. Rozmówca zwraca uwagę na pracowitość wietnamskich imigran-

Tabela 2. Metafory zwierząt przedstawiające przedsiębiorców wietnamskich pierwszego pokolenia imigrantów przebywających w Polsce

\begin{tabular}{|c|c|}
\hline Zwierzę & Uzasadnienie \\
\hline Lew & $\begin{array}{l}\text { - poluje i dba o swoją rodzinę } \\
\text { - działa z impetem } \\
\text { - a może puma lub gepard, ponieważ nie może być „,żadne zwierzę grupowe, bo } \\
\text { indywidualnie działają wszyscy” }\end{array}$ \\
\hline Mrówki & $\begin{array}{l}\text { - pracowite } \\
\text { - ziarnko po ziarnku } \\
\text { - pomocne sobie }\end{array}$ \\
\hline Lis & $\begin{array}{l}\text { - czasem chytry } \\
\text { - pracowity }\end{array}$ \\
\hline Pies & $\begin{array}{l}\text { - stadny } \\
\text { - lubiany przez klientów } \\
\text { - elastyczny }\end{array}$ \\
\hline Szczur & $\begin{array}{l}\text { - } \text { mądry } \\
\text { - } \text { kumuluje kapitał } \\
\text { - odważny } \\
\text { - } \text { postępuje po swojemu } \\
\text { - } \text { solidarny }\end{array}$ \\
\hline Bawół & $\begin{array}{l}\text { - ciężko pracuje, realizując swój cel } \\
\text { - bardzo sympatyczne zwierzę } \\
\text { - symbol pracy i nawet praca ponad normę } \\
\text { - wytrwały } \\
\text { - chociaż zmęczony, to będzie pracować }\end{array}$ \\
\hline
\end{tabular}

Źródło: opracowanie własne. 
tów. Podkreśla, że swoje sukcesy osiągają mozolną wytrwałą pracą, określając tę strategię jako zbieranie „ziarnko do ziarnka”. Badany uważa też, że przedsiębiorcy wietnamscy pomagają sobie i mogą na siebie liczyć w trudnych momentach. Podkreśla jednak, że mimo wzajemnej pomocy, każdy z przedsiębiorców pracuje sam na siebie, a nie na tzw. mrowisko. Działają indywidualnie, a nie razem. Ponadto, jego zdaniem, mrówki są dość bezpłciowe, natomiast Wietnamczycy mają bardzo różne charaktery i nie tworzą jednolitej masy.

Następnym zwierzęciem pojawiającym się ponownie jako metafora wietnamskiego przedsiębiorcy jest szczur. Cechy szczura, które porównywane są do cech wietnamskiego właściciela firmy to: odwaga, mądrość, niezależność, ale i oszczędność, ponieważ szczur kumuluje kapitał oraz jest solidarny z grupą.

Nowe rodzaje zwierząt, które się pojawiły jako metafory to: lew, lis oraz pies. Lis został wybrany przez badanego, ponieważ posiada takie cechy, jak chytrość i przebiegłość. Dodaje jednak, że ważną charakterystyką jest też pracowitość, a tego o lisie do końca nie można powiedzieć. Osoba, która wybrała lwa uzasadniała swój wybór tym, że Wietnamczycy mają działać z impetem, jak polujące lwy. Rozmówca zauważa, że dla lwów ważne jest dbanie o rodzinę - stado. Jednak to, co jego zdaniem nie pasuje do Wietnamczyków to fakt, że raczej działają indywidualnie niż w zwartej grupie. Dlatego też dodaje, że może lepszą metaforą byłaby puma albo gepard, które jego zdaniem działają samotnie. Ponadto lew nie jest oszczędny, a to, jak podkreśla rozmówca, jest ważne dla wietnamskiej społeczności przedsiębiorców pierwszego pokolenia, która kumuluje kapitał.

Kolejny przedsiębiorca opisujący swoich pobratymców należących do pierwszego pokolenia uważa, że Wietnamczycy są jak psy - mają łagodną i sympatyczną naturę. Są zwierzętami stadnymi i dość elastycznymi w działaniu. Co różni ich jednak od psów, to duże rozkojarzenie oraz zabieranie się za wiele rzeczy w jednym momencie. Często prowadzą wiele różnych interesów i niewiele rzeczy doprowadzają do końca.

Jak można zauważyć, ponownie pracowitość jest dość mocno podkreślana w metaforach. Tym razem jednak bardziej podkreślana była zaradność i skuteczność działania. Pojawiały się również opinie, z których wynika, że Wietnamczycy korzystają z siły grupy, aby realizować indywidualne cele, ale nie pracują na rzecz społeczności, każdy działa samodzielnie. Doceniają jednak swoją społeczność jako kapitał.

Trochę inne zwierzęta znajdą się przy metaforach przedsiębiorców należących do drugiego pokolenia. Przykłady tych metafor przedstawiono w tabeli 3 .

W metaforach dotyczących drugiego pokolenia pojawiają się nowe gatunki zwierząt. Przede wszystkim pojawiają się ptaki - symbol wolności oraz zwierzęta łączące dwa światy, lądowy i powietrzny. Można już wyraźnie zobaczyć różnicę w charakterystyce drugiego pokolenia w porównaniu z pierwszym. Na początku analizie poddano zwierzęta które już się pojawiały we wcześniejszych porównaniach.

Pies w przypadku drugiego pokolenia ma symbolizować, że Wietnamczycy dopiero stają się zwierzętami stadnymi. Zaczynają się integrować ze społecznością polską. Pojawia się też taka cecha, jak wierność ideałom. Podkreślane są też różne temperamenty i rodzaje psów, które symbolizują przedsiębiorców wietnamskich.

W metaforach dotyczących ogólnie wietnamskich przedsiębiorców pojawiał się wąż. Jest on wspominany ponownie, tym razem charakteryzując jednak wyłącznie drugie pokolenie. W tym przypadku uwypuklone są takie cechy, jak: cierpliwość oraz mądrość, a także umiejętność koncentracji na jednym celu, na którego osiągnięcie wietnamscy przedsiębiorcy potrafią skupić cała swoją energię, aby skutecznie uderzyć.

Nowym zwierzęciem w porównaniach jest aligator. Badanemu przedsiębiorcy aligator kojarzył się z młodymi przedsiębiorcami, przede wszystkim jako stworzenie, które biernie czeka na swoją ofiarę, aż sama wpadnie mu w paszczę. Ponadto, według badanego, młodzi nie działają razem, a indywidualnie. Natomiast, jeśli już zaczynają współpracować, to nie obawiają się kooperacji z Polakami. Badany przyrównuje to do międzygatunkowej współpracy, którą można zaobserwować pomiędzy aligatorem i pewnym gatunkiem ptaka, który czyści mu zęby, pożywiając się pozostałymi między nimi resztkami pokarmu. Ponadto młodzi przedsiębiorcy lubią kierować, ale już nie do końca mają chęć do ciężkiej pracy. Szybciej kogoś zatrudnią, żeby wykonał dla nich jakąś pracę niż sami się 
Tabela 3. Metafory zwierząt przedstawiające przedsiębiorców wietnamskich drugiego pokolenia imigrantów przebywających w Polsce

\begin{tabular}{|c|c|}
\hline Zwierzę & Uzasadnienie \\
\hline Aligator & $\begin{array}{l}\text { - lubi żeby inni za niego pracowali } \\
\text { - żyje między dwoma gatunkami } \\
\text { - czeka na zyski }\end{array}$ \\
\hline Wolny ptak & $\begin{array}{l}\text { - niezależni } \\
\text { - każdy idzie w swoim kierunku }\end{array}$ \\
\hline Pies & $\begin{array}{l}\text { - Wietnamczycy zaczynają być zwierzęciem stadnym } \\
\text { - asymilują się i wychodzą poza swoje „podwórko” } \\
\text { - różne charaktery, temperamenty } \\
\text { - wierni ideałom }\end{array}$ \\
\hline Młody wilk & $\begin{array}{l}\text { - młodzi nie potrafią jeszcze być w stadzie } \\
\text { - samotni } \\
\text { - idą swoją drogą }\end{array}$ \\
\hline Wąż & $\begin{array}{l}\text { - potrafią skupić energię na jednym uderzeniu } \\
\text { - koncentrują uwagę na jednym celu } \\
\text { - mądrzy } \\
\text { - cierpliwi }\end{array}$ \\
\hline Orzeł & $\begin{array}{l}\text { - } \text { bardziej drapieżni } \\
\text { - } \text { pracują, ale też lubią się bawić } \\
\text { - korzystają z życia } \\
\text { - na orła trzeba uważać, już też potrafią walczyć, nie zrobi tyle ile każą }\end{array}$ \\
\hline Leniwiec & - rozleniwili się w stosunku do pierwszego pokolenia \\
\hline
\end{tabular}

Źródło: opracowanie własne.

nia zajmą. Jest też grupa przedsiębiorców, która po prostu pasożytuje na rodzicach, przejmując ich firmy i nie wprowadzając jakichkolwiek ulepszeń.

Ciekawe jest również porównanie przedsiębiorców z drugiego pokolenia do wolnych ptaków, które są niezależne i w przeciwieństwie do swoich rodziców nie boją sie realizować marzeń. Choć kolejny badany używa metafory orła, to uzasadnienie wyboru tego zwierzęcia jest nieco inne. Orzeł należy do ptaków drapieżnych i jest jednym z najsilniejszych. Potrafi zabijać o wiele wieksze od siebie zwierzeta. Właśnie przed tą drapieżnością orłów przestrzega badany, wypowiadając się o drugim pokoleniu. Podkreśla, że są to już osoby, które potrafia walczyć o swoje i nie sa już tak uległe, jak rodzice. Lubią pracować, ale potrafią też się bawić i cenią sobie swój czas wolny. Nie dają się już wykorzystywać i potrafią korzystać z życia, z możliwości jakie mają.
Młody wilk jest również metafora drugiego pokolenia. Rozmówczyni uważa młodych przedsiębiorców za niezależnych, a być może nawet i samotnych w swoim dążeniu do osiągnięcia sukcesu. Każdy idzie swoją drogą, ponieważ nie potrafią już funkcjonować w ,stadzie”.

Leniwiec został wybrany przez badanego, który uważa młodych Wietnamczyków wychowanych w Polsce za rozleniwionych w stosunku do pierwszego pokolenia.

Podsumowujac, zwierzeta użyte w tworzeniu metafor dla przedsiębiorców drugiego pokolenia Wietnamczyków przebywających w Polsce charakteryzują się przede wszystkim niezależnością, stanowczością i odwagą, a także mniejszą chęcią do ciężkiej pracy.

Porównując metafory zastosowane dla pierwszego i drugiego pokolenia, można zauważyć jak różnie postrzegane są te dwie grupy. Pierwsza ma charakteryzować sie ogromna pracowitościa, praca ponad 
normę i oszczędnością. Druga grupa to niezależni przedsiębiorcy, którzy zaczynają już współpracować z Polakami, praca jest dla nich ważna, ale równie ważne jest też ich życie prywatne i czas wolny. Często też korzystają z kapitału zgromadzonego przez rodziców.

\section{Wnioski}

Zestawienie metafor pokazuje, że część Wietnamczyków zauważa różnice między pierwszym a drugim pokoleniem przedsiębiorców wietnamskich funkcjonujących w Polsce. Można zauważyć, że ogólnie Wietnamczycy określali swoją społeczność, niezależnie od tego czy było to ogólnie o obu pokoleniach, czy każdego z osobna, jako społeczność bardzo zaradną i skupioną na osiagnięciu celów, choć te cele mogą być różne dla pokoleń. Dla pierwszego pokolenia celem działań jest oszczędzanie pieniędzy, aby mieć później lepsze życie, a dla drugiego pokolenia coraz ważniejsze jest korzystanie z życia i zarabianych pieniędzy. Konsumują w tym celu m.in. również pieniądze zgromadzone przez rodziców. Największe różnice między pokoleniami można zauważyć w podejściu do pracy. Pierwsze pokolenie jest skoncentrowane na pracy. Drugie pokolenie nie widzi potrzeby takiej pracy, jak pierwsze pokolenie, ponieważ korzysta z kapitału zgromadzonego przez rodziców i może sobie pozwolić na czas wolny i rozwijanie swoich pasji. Częściej także wchodzi we współpracę z Polakami. W większości przypadków badani podkreślali, że niezależnie od tego czy przedsiębiorca zaliczany byłby do pierwszego, czy do drugiego pokolenia Wietnamczycy nie lubią być widoczni w społeczeństwie. Wolą działać bez rozgłosu i spokojnie realizować swoje plany. Skupieni są na budowaniu dobrobytu. Mimo iż działają w grupie, nie jest to do końca działanie na grupę. Najważniejsze jest dobro rodziny. Społeczność jest narzędziem, które może dać siłę i wsparcie.

Użycie metafor w badaniu pozwoliło na przedyskutowanie $\mathrm{z}$ badanymi charakterystyk ich społeczności. W części projekcyjnej pojawiło się więcej wątków, w których badani pozwalali sobie na krytykę swojej społeczności. Można więc uznać, że narzędzie spełniło założenia. Jest to o tyle ważne, że w przypadku Azjatów, którzy nie lubią mówić o sobie, swojej społeczności i swoich wadach użycie metafor umożliwiło badanym opowiedzenie o swojej społeczności więcej niż gdyby zostali zapytani wprost.

\section{Bibliografia}

Andrejuk, K. (2016). Co skłania imigrantów do zakładania własnych firm? Analiza procesu samozatrudniania i rozwijania przedsiębiorstw etnicznych na przykładzie społeczności Ukraińców w Polsce. Studia Migracyjne - Przeglad Polonijny, 3(161) 223-253.

Auster, A. i Aldrich, H.E. (1984). Small business vulnerability, ethnic enclaves and ethnic enterprise. W: R. Ward, R. Jenkins (red.), Ethnic Communities in Business (s. 39-58). New York: Cambridge university Press.

Babbie, E. (2008). Podstawy badań spotecznych. Warszawa: Wydanictwo Naukowe PWN.

Bellenger, D.N., Bernhardt K.L. i Goldstucker, J.L. (1976). Qualitative Research in Marketing. Chicago: American Marketing Association.

Branthwaite, A. i Lunn T. (1985). Projective Techniques in Social Market research. W: R.W. Aldershot (red.), Applied Qualitative Research (s. 101-121). England: Gower Publishing Company.

Burton, J.W. (1974). Some Nuer notions of purity and danger. Dedicated to the memory of E.E. Evans-Pritchard (1902-1973). Anthropos, 69(3/4), 517-536.

Castles, S. i Miller, M.J. (2011). Migracje we wspótczesnym świecie. Warszawa: Wydawnictwo Naukowe PWN.

Dubel, P. (2006). Rola i metody wspierania sektora Małych i Średnich Przedsiębiorstw w Unii Europejskiej. Studia i Materiaty, 2, 112-117.

Dubel, P. (2017). Wpływ funduszy unijnych na rozwój przedsiębiorczości po akcesji Polski do UE - przegląd wybranych form wsparcia. Studia i Materiaty, 23, 135-152. https://doi. org/10.7172/1733-9758.2017.23.13.

Dyson, A.H. i Genishi, C. (1994). The need for story: Cultural diversity in classroom and community. Urbana, IL: National Council of Teachers of English.

Glinka, B. (2018). Immigrant Entrepreneurship as a Field of Research. Problemy Zarzadzania, 16 , 25-39. https://doi.org/10.7172/1644-9584.73.2.

Glinka, B. i Brzozowska, A. (2015). Immigrant Entrepreneurs: in Search of Identity. Entrepreneurial Business and Economics Review, 3, 51-76. https://doi.org/10.15678/EBER.2015.030304.

Glinka, B. i Hensel, P. (2018). What Should Be Avoided During Qualitative Research?. W: M. Ciesielska, D. Jemielniak (red.), Qualitative Methodologies in Organization Studies (s. 245-257). Palgrave 
Macmillan, Cham. https://doi.org/10.1007/978-3319-65442-3_11.

Górny, A. (2007). Położenie i zachowania imigrantów na mazowieckim rynku pracy. W: A. Górny, A. Grzymała-Kazłowska, E. Kępińska, A. Fihel, A. Piekut (red.), Od zbiorowości do spoteczności: rola migrantów osiedleńczych $w$ tworzeniu się spoteczności imigranckich $w$ Polsce (s. 69-86). Center of Migration Research, Centre of Migration Research Faculty of Economic Sciences Warsaw University.

GUS. (2015). Imigracje. Pobrano z: http://demografia. stat.gov.pl/bazademografia/Tables.aspx (01.04.2019).

Jung, C.G. (1981). Archetypy i symbole. Warszawa: PWN.

Kępińska, E. (2005). Recent Trends in International Migration. The 2005 SOPEMI Report for Poland. CMR Working Papers, Seria Prace Migracyjne, 2(60). Warszawa: Uniwersytet Warszawski.

Kloosterman, R.C. i Rath, J. (2010). Shifting landscapes of immigrant entrepreneurship. W: OECD, Open for Business, Migrant entrepreneurship in OECD countries (s. 86-108). OECD Publishing. http://dx.doi.org/10.1787/9789264095830-en.

Konecki, K. (2000). Studia z metodologii badań jakościowych: teoria ugruntowana. Warszawa: PWN

Krueger, R.A. (1994). Focus Groups: A Practical Guide for Applied Research. Thousand Oaks, CA: Sage.

Light, I. i Bonacich, E. (1988). Immigrant entrepreneurs: Koreans in Los Angeles 1965-1982. Oakland, CA: University of California Press.

Maison, D. (2010). Jakościowe metody badań marketingowych. Jak zrozumieć konsumenta. Warszawa: Wydawnictwo Naukowe PWN.

Manev, I.M., Gyoshev, B.S. i Manolova, T.S. (2005). The role of human and social capital and entrepreneurial orientation for small business performance in a transitional economy. International Journal of Entrepreneurship and Innovation Management, 5, 298-318.

Min, P.G. i Bozorgmehr, M. (2003). USA: the entrepreneurial cutting edge. W: R. Koosterman, J. Rath (red.), Immigrant Entrepreneurs: Venturing Abroad in the Age of Globalization. Berg: Oxford.
Morgan, G. (2006). Images of Organization. Thousand Oaks, CA: Sage Publications.

Neal, A.G. (1985). Animism and Totemism in Popular Culture. Journal of Popular Culture, 19(2), 15-24.

Nowicka-Rusek, E. (2008). Adaptacja, asymilacja i izolacja Wietnamczyków w Polsce. W: M. Kulesza, M. Smagowicz (red.), Wietnamczycy w Polsce (s. 22-55). Warszawa: Instytut Profilaktyki Społecznej i Resocjalizacji UW MCAZ.

Pawłowska, A. i Postuła, A. (2014). Pracownik i pracodawca: wykorzystanie technik projekcyjnych w badaniu postrzegania wzajemnych relacji. Problemy Zarzadzania, 12(1), 30-49.

Rorty, R. (1999). Obiektywność, relatywizm i prawda. Warszawa: Aletheia.

Sax, B. (1988). Anthromorphism in Animal Encyclopedias of nineteenth Century America. New York Folklore, 14(1), 107-122.

Silverman, D. (2008). Prowadzenie badań jakościowych. Warszawa: Wydawnictwo Naukowe PWN.

Spears, N.E., Mowen, J.C. i Chakraborty, G. (1996). Symbolic role of animals in print advertising: Content analysis and conceptual development. Journal of Business Research, 37, 87-95.

Trompenaars, F. i Hampden-Turner, C. (1999). Riding the Waves of Culture. Understanding Cultural Diversity in Business. London: Nicholas Brealley Publishing.

Tylor, E.B. (1989). Remarks on Totemism, with Especial Reference to Some Modern Theories Respecting It. The Journal of the Anthropological Institute of Great Britain and Ireland, 28(1/2), 138-148.

Waldinger, R., Aldrich, H. i Ward, R. (1990). Ethnic Entrepreneurs: Immigrant Business in Industrail Societies. Newbury Park, CA: Sage Publications.

Wysieńska, K. i Piłat, A. (2012). Ekonomiczna adaptacja chińskich i wietnamskich migrantów zarobkowych. W: K. Wysieńska (red.), Sprzedawać, gotować, budować? Plany i strategie Chińczyków $i$ Wietnamczyków w Polsce. (s. 99-118). Warszawa: Instytut Spraw Publicznych. 